\title{
Dynamic of arm's micro movements of elite athlete in Olympic exercises Rapid Fire Pistol and Air Pistol
}

\author{
Pyatkov V.T. ${ }^{1}$, Bilinski J. ${ }^{2}$, Petriv O.S. ${ }^{3}$, Magmet T.M. ${ }^{4}$ \\ ${ }^{1}$ Lviv State University of Physical Culture \\ ${ }^{2}$ University of Information Technology and Management in Rzeszow, Poland \\ ${ }^{3}$ Ukrainian Defense Ministry of Sport Management \\ ${ }^{4}$ National Academy of Internal Affairs
}

\begin{abstract}
Purpose:

to scientifically substantiate the method of contactless determination of athlete hand's movements in Olympic exercises with pistol.

Material: $\quad$ in the research we used the data of 37 elite athletes in exercise Air Pistol ( $n=32$ ) and in exercise Rapid Fire Pistol $(n=5)$. Registration of pistol projection's quickness of movement in target area was realized with the help of computer system Scatt. In total we analyzed 3100 space-time parameters of athletes' technical-tactic actions in finalizing phase of shooting cycle.

Results: $\quad$ we tested innovative method of contactless measuring of athlete's hand's micro movements in finalizing phase of shooting cycle. We found uncontrolled deviations from optimal pistol pointing position in vertical, horizontal and sagittal planes. Quickness of athlete hand's movements in shooting process was determined.

Conclusions: we scientifically substantiated the method of contactless determination of athlete hand's movements at a distance in Olympic exercises with pistol. Besides, we determined the dynamic of athlete's hand micro movements in Olympic exercises Rapid Fire Pistol ta Air Pistol.

Keywords: $\quad$ sports, shooting, pistol, method, micro movements, dynamic
\end{abstract}

\section{Introduction}

Sport rivalry is constantly increasing on international arena, in particular at Olympic Games in exercises Rapid Fire Pistol (pistol target shooting for quickness from 25 meters distance) and Air Pistol (air pistol shooting from distance 10 meters). Accordingly demand in scientific improvement of scientific methodic provisioning of athletes' training for official international competitions is also increasing. Due to own specific features sport shooting endures great demand in control devices with objective registration of space characteristics. Elite athletes especially need to control all complex structure of shooting technique, in order to find reserves for its elements' improvement.

In the base of shooting technique's improvement (for different kinds of arm) there are qualitative and quantitative changes of its micro-structure characteristics. The main reason of problems in motor technique is the fact that coaches (and athletes also) has deficiency of objective assessments of skillfulness and control over its perfection [9].

Alongside with it, the problem of registration and analysis of athlete hand's micro movements has been studied insufficiently. In particular, uncontrolled changes of optimal position in sagittal plane have not been studied. However, statistically confident data about movements on axis $\mathrm{Z}$ are the necessary component, which is absent in scientific-methodic provisioning of athletes' training. The known methods can not be applied in competition conditions, where accurate data are especially important.

So, the problem of contactless remote registration of athlete hand's micro movements in pistol shooting process in Olympic exercises has become rather relevant.

In the field of sports there are prolonged researches of Olympic and professional sports problems [24-29] as well (C) Pyatkov V.T., Bilinski J., Petriv O.S., Magmet T.M., 2017 doi:10.15561/20755279.2017.0207 as the questions of athletes-shooters' trainings perfection. For example, the main conditions of accurate rifle pointing were studied by N.A. Kalinichenko [4]; light filters in diopter sights were offered. A.M. Kovalchuk worked out the system of professional-shooting training optimization for officers of Home Affairs' of Ukraine units [5]. The problems of shooters' technical-tactic training in applied sport exercises were researched by S.M. Banakh [1]. I.P. Zanevskiy and Yu.S. Korostyliova fulfilled a number of important studies on air pistol shooting within system "Shooter - Weapon" $[3,6]$. But determination of spacetime parameters in system "Shooter-Weapon-Target" requires additional studies [7-11].

It should be noted that as on the present moment in the field of sports changes of movements' coordinates by axes $\mathrm{X}$ and $\mathrm{Y}$ have been studied: on the base of sport simulators in volleyball, swimming and other kinds of sports [2, 1518]. It is the fact that technologies' progress in sports accelerates [19-23]. And it means that new methods of data obtaining and processing shall be improved on the base of computerization [30-32].

At the same time we have not found any works about statistically confident parameters of athlete's micro movements by axis $\mathrm{Z}$ in exercises Rapid Fire Pistol and Air Pistol.

Considering modern technological achievements we assumed that computer technologies will make possible to simulate contactless measuring of athlete's hand micro movements in pistol exercises. Practical value of such researches implies perfection of scientific-methodic provisioning of athletes' training [12-14].

The purpose of the work is to scientifically substantiate the method of contactless determination of athlete hand's movements by axis $\mathrm{X}, \mathrm{Y}$ and $\mathrm{Z}$ and micro movements dynamic in Olympic exercises Rapid Fire Pistol and Air Pistol. 


\section{Material and methods}

Participants: in the research we used the data of 37 elite athletes: international masters of sports in exercise Air Pistol $(n=32$, including 8 member of initial staff of Combined team of Ukraine in bullet shooting); in exercise Rapid Fire Pistol ( $n=5,2$ of them - Champions of Olympic Games and 1 - winner and 2 - prize winners of World Cup).

Organization of the research: electronic-optical registration of pistol's projection quickness in the area of target during shooting was realized with the help of computer system Scatt [10]. In total we analyzed 3100 space-time parameters of athletes' technical-tactic actions in finalizing phase of shooting cycle.

Statistical analysis: the materials were statistically processed with the help of Microsoft Excel 2010 software.

In the process of the research we had to solve the following tasks:

- Testing of contactless registration model for spacetime parameters of athlete hand's micro movements by axes $\mathrm{X}, \mathrm{Y}$ and $\mathrm{Z}$;

- Find out the presence or absence of changes of athlete hand's coordinated by sagittal axis $\mathrm{Z}$ in the process of pointing;

- Determine the dynamic of athletes-shooters hands' micro movements in Olympic exercises Rapid Fire Pistol and Air Pistol;

- Offer the method of remote express analysis, diagnostic and correction of athlete's pre-start readiness at official international competitions;

- Work out practical recommendations.

\section{Results}

We tested the model of contactless registration of athlete hand's movements in the process of Olympic pistol exercises' fulfillment. The model is called CEA16
(Contactless Electronic Analysis). Its distinctive feature is that it simultaneously registers micro movements by axes XYZ in exercises Rapid Fire Pistol and Air Pistol on the base of contactless sensors [26], (see fig. 1).

The device is characterized by high accuracy and frequency of pictures. Besides, it provides reports about discrete positions and movements. Controller uses optical sensors and infra-red light. New interactive model CEA16 permits to measure physical values in the following units: distance - millimeters; time - micro-seconds; velocity $\mathrm{mm} / \mathrm{sec}$; angle of view - radian.

In CEA16 software internal model of human hand is used. The model prognosticates tracing, even if a part of hand is not visible. The model always ensures positions for five fingers. Tracing is optimal, when a contour of hand and fingers is clearly visible. CEA16 analyzes visible parts of hand and its internal models. The system analyzes results of previous tracings for calculation of the most probable positions of the parts, which are not visible at the given moment. Super sensitive sensors of model CEA16 movements' controller can identify different human micro movements with preciseness $0.001 \mathrm{~mm}$. CEA16 visual analyzer identifies and traces hand and fingers (see fig. 2).

With the help of CEA16 it is possible to measure micro movements of two athletes simultaneously, for expresscomparison their potentials. Though we recommend keeping not more than two objects in the area of controller sensors' action for optimal quality of micro movements' tracing.

On the base of CEA16 model (puc. 2) we tested the method of contactless remote measurement of athlete hand's micro movement space-time parameters in the process of Olympic exercises' fulfillment. Earlier such data were unknown in theory and practice and not mentioned in scientific literature.

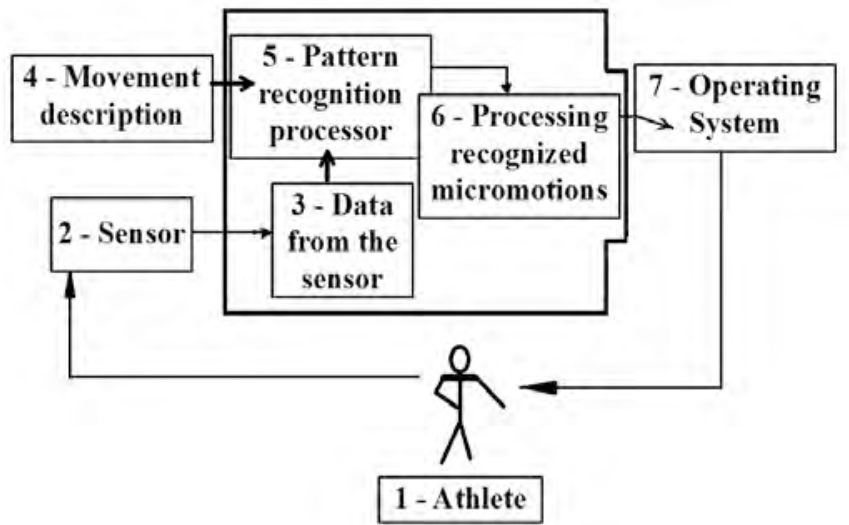

Fig.1. Block diagram of CEA16 model for registration micro movements by XYZ axes:

1 - sportsman in start position for Rapid Fire Pistol exercise;

2 - remote sensor Leap Motion;

3 - data from remote sensor;

4 - description of athlete hand's movement in finalizing phase of shooting;

5 - processor of identification of movement's images;

6 - processing of identified micro movements;

7 - operational system of computer. 


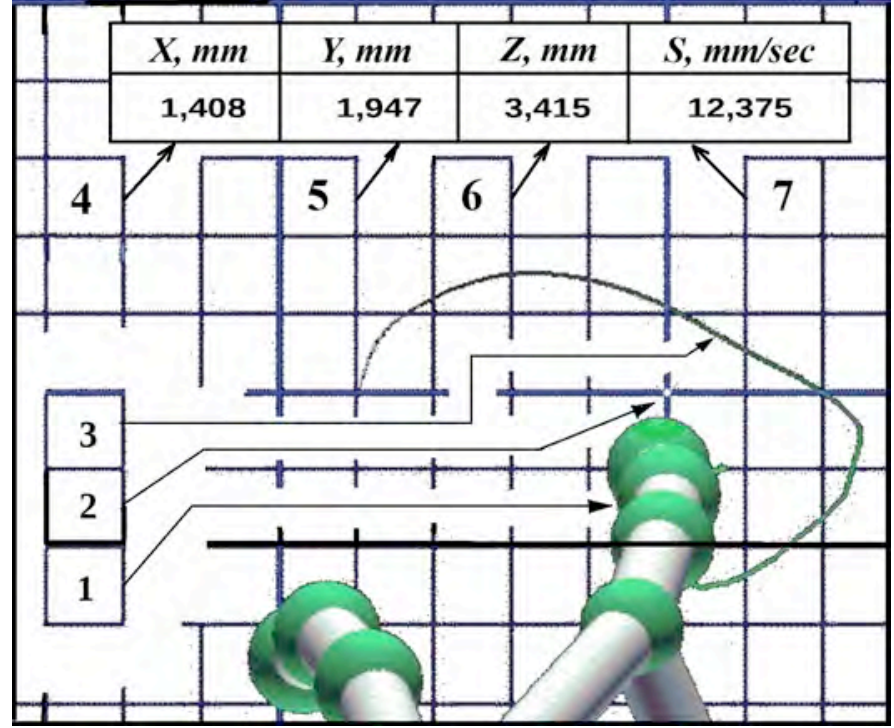

Fig. 2. Visual analyzer of micro movements in interactive model CEA16:

1 - athlete's index finger;

2 - area of "aiming";

3 - trajectory of athlete hand's moving in the process of pointing;

4 - coordinates of athlete's hand by axis $X$ in the moment of registration;

5 - coordinates of athlete's hand by axis $Y$ in the moment of registration;

6 - coordinates of athlete's hand by axis $Z$ in the moment of registration;

7 - velocity of athlete hand's moving at the moment of registration.

New model CEA16 is an aggregate of program and apparatus means, which trace movements with their further transformation in parameters of axes $\mathrm{X}, \mathrm{Y}$ and $\mathrm{Z}$. Model CEA16 permits to use computer in completely new way: to trace positions of athlete's hand with speed of 200 pictures per second with the help of infra-red cameras in 3-D space.

The method implies visualization of athlete hand's micro-movements in the process of pressing trigger. The offered name of the method of micro-movements' measurement in the process of pressing trigger is Micro Movements of Sportsman (MMS).

1. With the help of MMS method we measured the most important space-time parameters of athlete hand's micro movements in fulfillment of Olympic exercises Rapid Fire Pistol and Air Pistol (табл. 1).

2. Thus, we have solved the problem of contactless remote registration of athlete hand's micro movements in the process of pistol shooting in fulfillment Olympic exercises.

3. We also found boundary values of the studied parameters for elite shooters in the process of pressing trigger. Mean value of horizontal deviations of athlete's hand is $1.557 \mathrm{~mm}$.

4. Horizontal deviations are within $1.226 \div 2.042 \mathrm{~mm}$; mean vertical deviation of athlete's hand from the required position was $1.941 \mathrm{~mm}$; vertical oscillations of athlete's hand in finalizing phase of pressing trigger were within $1.931 \div 1.990 \mathrm{~mm}$.
5. Mean sagittal deviations of athlete's hand from the required position was $3.415 \mathrm{~mm}$; sagittal oscillations of athlete's hand in finalizing phase of pressing trigger were within $3.124 \div 5.099 \mathrm{~mm}$; mean velocity of athlete hand's movement in finalizing phase of pressing trigger was $12.345 \mathrm{~mm} / \mathrm{sec}$; velocity of athlete hand's movement in finalizing phase of pressing trigger was within $11.548 \div 14.343 \mathrm{~mm} / \mathrm{sec}$.

On this base we affirm that in shooting Olympic exercises (Rapid Fire Pistol and Air Pistol) we statistically confidently registered micro movement in planes $X, Y, Z$ (see fig. 3).

As a result of this fact, velocity of athlete hand's movements in finalizing phase of pressing trigger is a variable value (see fig. 3), that conditions significant influence on efficiency of exercises' fulfillment.

The confidence of results is proved by accuracy of computer analysis of the received data.

So, in the present work we supplied theoretical generalization and new solution of technical-tactic parameters' express-registration in finalizing phase of pressing trigger. It permits to objectively determine an athlete's condition and its correcting, especially in competitions. The problem has been solved with the help of MMS method. Thus, for the first time, scientific substantiation of micro movements' computer registration has been realized for Olympic exercises Rapid Fire Pistol and Air Pistol in sagittal plane (3D) with the help of model CEA16. 
Table 1. Athlete hand's micro movements in the process of CEA16 testing, $p<0.05$

\begin{tabular}{lllll}
\hline $\begin{array}{l}\text { THE MEASURED PARAMETERS } \\
\text { Attempts }\end{array}$ & Deviation by $X, m m$ & Deviation by $Y, m m$ & Deviation by $Z, m m$ & $\begin{array}{l}\text { Velocity } \\
\text { S } m / s e c .\end{array}$ \\
\hline $\mathbf{1}$ & 1.408 & 1.947 & 3.415 & 12.375 \\
$\mathbf{2}$ & 1.819 & 1.939 & 3.144 & 11.848 \\
$\mathbf{3}$ & 1.518 & 1.937 & 3.515 & 12.475 \\
$\mathbf{4}$ & 1.405 & 1.939 & 3.544 & 11.548 \\
$\mathbf{5}$ & 1.914 & 1.942 & 3.412 & 12.315 \\
$\mathbf{6}$ & 1.931 & 3.124 & 11.818 \\
$\mathbf{7}$ & 1.389 & 1.942 & 3.415 & 12.675 \\
$\mathbf{8}$ & 1.226 & 1.933 & 3.256 & 11.648 \\
$\mathbf{9}$ & 1.714 & 1.981 & 3.549 & 13.248 \\
$\mathbf{1 0}$ & 1.596 & 1.990 & 5.099 & 14.343 \\
\hline
\end{tabular}

Notes: $\quad \mathrm{X}, \mathrm{mm}-$ horizontal deviations of athlete's hand;

$\mathrm{Y}, \mathrm{mm}$ - vertical deviations;

$\mathrm{Z}, \mathrm{mm}$ - deviations in sagittal plane;

$\mathrm{S}, \mathrm{mm} / \mathrm{sec}$ - velocity of athlete hand's moving at the moment of registration.

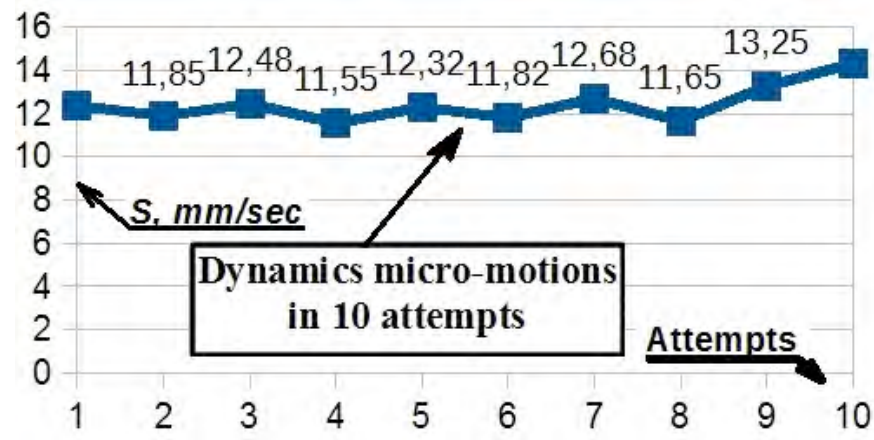

Fig. 3. Dynamic of elite shooters hands' micro movements in 10 series of exercise Air Pistol

\section{Discussion}

Comparing with technologies of Scatt system [10] CEA16 model ensures athletes' training by more informative interface through ordinary USB port. The system registers movements with the help of remote analysis of gestures. It is difficult to imagine the progress of scientific-methodic provisioning of elite sportsmenshooters without CEA16 technology of gestures' identification. Our results expand significantly the data of other studies [3, 4, 5].

The prospects of other findings in this direction imply addition of new systems to controller of model CEA16. Practical recommendations: for registration space-time parameters direct indicators of model CEA16 to exchange buffer (pressing key PrtSc) and insert it in addition (Paint, Writer, pressing key Shift+Insert). In the process of the model's adjustment it is necessary to see device in action without touching keyboard, mouse or screen.

The next important moment is determination of the most convenient height of tracking, which is to be adjusted in options. In our testing the most convenient was standard value $-20 \mathrm{~cm}$. If to work in sitting position (like in exercises of Para-Olympic sportsmen) it is necessary to reduce the height a little or use automatic tracking.

Concerning working out devices for children-junior sport schools, in model CEA16 program language Unity $3 D$ is suitable. The model's controller permits to control computer with the help of hands' gestures in space. Now, interaction with computer in Windows 10 is possible, with realization of full spectrum of opportunities (complete support of multi-touch gestures).

It should be reminded that sensitivity level of $C E A 16$ controller permits to trace even fine movements of fingers that expand its opportunities. The model itself has not big size.

Connection to computer is through USB interface. With it, accuracy of micro movements' tracing reaches $1 / 100 \mathrm{~mm}$. Besides, it is possible to adjust this system 
for individual gestures and sensitivity parameters to meet own technical-tactic actions.

Thus, scientific information about dynamic of athlete's micro movements in Olympic exercises Rapid Fire Pistol and Air Pistol has been developed.

\section{Conclusions}

In the present work we have solved the problem of contactless remote registration of athlete hand's micro movements in the process of pistol shooting in fulfillment Olympic exercises.

The problem has been solved with the help of innovative remote method of computer express-analysis of hand's coordinate changes by vertical, horizontal and sagittal axes simultaneously. Earlier it was impossible in practice and such information is not mentioned in scientific literature.

We have tested innovative model of contactless registration of athlete hand's movements in the process of Olympic pistol exercises' fulfillment.

The values of registered hand's micro movements in pointing position are as follows: vertical oscillations $1.931 \div 1.990 \mathrm{~mm}$; horizontal oscillations $-1.226 \div 2.042$ $\mathrm{mm}$; sagittal micro movements - 3.124 $\div 5.099 \mathrm{~mm}$; velocity of hand's movement is $11.548 \div 14.343 \mathrm{~mm} / \mathrm{sec}$.

\section{Conflict of interests}

The author declares that there is no conflict of interests.

\section{References:}

1. Banakh SM. Racional'na trivalist' vikonannia shvidkisnikh sportivno-prikladnikh strilec'kikh vprav [Rational duration of sport-applied shooting exercise's fulfillment]. Pedagogics, psychology, medical-biological problems of physical training and sports, 2002;26:37-39.

2. Iermakov SS. Navchannia tekhnici udarnikh rukhiv u sportivnikh igrakh na osnovi ikh komp'iuternikh modelej ta novikh trenazhernikh pristroiv. Dokt. Diss. [Training of strike movements in sport games on the base of their computer models and new simulators. Doct. Diss.], Kiev; 1997, (in Ukrainian)

3. Zanevs'kij IP, Korostil’ova IuS, Mikhajlov VV. Tochka priciliuvannia na optoelektronnij misheni pri riznikh vidakh stril'bi z pnevmatichnogo pistoleta [The aiming point on opto-electronic target in different kinds of air istol shooting]. Fizichna aktivnist', zdorov'ia i sport, 2011;1 (3):12-22. (in Ukrainian)

4. Kalinichenko NA. Osnovnye usloviia, povyshaiushchie tochnost'pricelivaniia pri strel'be iz vintovki s dioptricheskim pricelom. Kand. Diss. [Main conditions increasing aiming accuracy in rifle with diopter sight shooting. Cand. Diss.], Moscow; 1969. (in Russian)

5. Koval'chuk AM. Trenazherna model' strilec'kikh vprav u pidrozdilakh MVS Ukraini [Training model of shooting exercises in MHA units of Ukraine]. Slobozhans 'kij naukovosportivnij visnik, 2001;3:79-80. (in Ukrainian)

6. Korostil'ova Iu. Trenuval'ni postrili z vikoristanniam stisnutogo povitria na etapi specializovanoi bazovoi pidgotovki stril'civ z pnevmatichnogo pistoleta [Training shots with ompressed air at stage of specialized training of air pistol shooters]. Moloda sportivna nauka Ukraini, 2011;15(1):134 - 141. (in Ukrainian)

7. Pavliuk IeO. Udoskonalennia stril'bi po rukhomikh misheniakh [Perfection of shooting at moving targets]. Pedagogics, psychology, medical-biological problems of physical training and sports, 2003;13:59-64.

8. Pyatkov VT. Teoriia i metodika strilec'kogo sportu [Theory an methodic of shooting sports], Lviv: Intelligence-West; 1999. (in Ukrainian)

9. Pyatkov VT. Specifika pidgotovki zbirnoi komandi Ukraini z kul'ovoi stril'bi do XXVII Olimpijs'kikh igor [Speific of training of combined team of Ukraine (bullet shooting) for 27th Olympic Games], Kiev: Scientific World; 2000. (in Ukrainian)

10.Pyatkov-Mel'nik VT. Strilec'ko-sportivna nauka Ukraini (2001-2005) [Shooting-sport science of Ukraine (2001-
2005)]. Sportivna nauka Ukraini, 2006;6(7);10-15. (in Ukrainian)

11.Rudij RM. Logichna organizaciia sistemi udoskonalennia tekhniko-taktichnoi pidgotovki stril'civ $\mathrm{z}$ pistoleta $\mathrm{u}$ klasifikacijnikh vpravakh olimpijs'koi programi [Logical organization of technical-tactic perfection for shooters in qualification exercises of Olympic program]. Sportivna nauka Ukraini, 2009;4:48-57. (in Ukrainian)

12.Ahmed Gaballah, Hamdy Elnawasry, Jose A Santos, Eadric Bressel. The Effect of Pilates Exercise with Sage Herbal Consumption on Respiratory Functions for Soccer Players. American Journal of Sports Science and Medicine, 2016;4(4):103-108.

13.Araújo R, Mesquita I, Hastie P. Review of the Status of Learning in Research on Sport Education: Future Research and Practice. Journal of Sports Science and Medicine, 2014;13:846-858.

14.Araújo R, Mesquita I, Hastie P, Pereira C. Students' game performance improvements during a hybrid sport educationstep-game-approach volleyball unit. European Physical Education Review, 2016;22:185-200.

15.Bradley J, Kerr S, Bowmaker D, Gomez J-F. Review of Shoulder Injuries and Shoulder Problems in Competitive Swimmers. American Journal of Sports Science and Medicine, 2016;4(3):57-73.

16.Casey A, Goodyear VA. Can Cooperative Learning Achieve the Four Learning Outcomes of Physical Education? A Review of Literature. Quest, 2015;67:56-72.

17.Elif Top. The Effect of Swimming Exercise on Motor Development Level in Adolescents with Intellectual Disabilities. American Journal of Sports Science and Medicine, 2015;3(5):85-89.

18.Farias C, Mesquita I, Hastie PA. Game Performance and Understanding within a Hybrid Sport Education Season. Journal of Teaching in Physical Education, 2015;34:363383.

19.Gutiérrez D, Garcia-Lopez L. Gender differences in game behaviour in invasion games. Physical Education and Sport Pedagogy, 2012;17:289-301.

20.Harvey S, Jarret K. A review of the game-centred approaches to teaching and coaching literature since 2006. Physical Education and Sport Pedagogy, 2014;19:278-300.

21.Hastie PA, Calderón A, Rolim R, Guarino AJ. The Development of Skill and Knowledge During a Sport Education Season of Track and Field Athletics. Research Quarterly for Exercise and Sport, 2013;84:336-344.

22.Lodewijkx, Hein F.M., and Arjan E.R. Bos. Lance 
Armstrong's Era of Performance — Part II: Revisiting His Time Trial Wins. American Journal of Sports Science and Medicine, 2014;2(5): 194-201.

23.Hiroki Aoki, Shinichi Demura, Masato Ohno. Eyes Open/ Closed Conditions and Age-level Differences in Foot Pressure during Stepping with a Stipulated Tempo. American Journal of Sports Science and Medicine, 2017;5(1):1-4.

24.Joshua Miller, Yunsuk Koh, Chan-Gil Park. Effects of Power-based Complex Training on Body Composition and Muscular Strength in Collegiate Athletes. American Journal of Sports Science and Medicine, 2014;2(5): 202-207.

25.Mesquita I, Farias C, Hastie PA. The impact of a hybrid Sport Education-Invasion Games Competence Model soccer unit on students' decision making, skill execution and overall game performance. European Physical Education Review, 2012;18:205-219.

26.Mischa Spiegelmock. Leap Motion Development Essentials. Birmingham: UK; 2013.

27.Rachael Irving. Transitional Nurturing Determines Performance in Elite Sprinting. American Journal of Sports Science and Medicine, 2016;4(3):74-77.
28.Rita R Culross. A Talent Development Perspective on the Olympic Athlete. American Journal of Sports Science and Medicine, 2015;3(5):108-111.

29.Shinji Tsubouchi, Shinichi Demura, Yu Uchida, Yoshimasa Matsuura, Hayato Uchida. Agility Characteristics of Various Athletes Based on a Successive Choice-reaction Test. American Journal of Sports Science and Medicine, 2016;4(4):98-102.

30.Takahashi Kenji, Shin-ichi Demura. Age-related Differences in Grip Strength Laterality in Male Elite Soft-tennis Players. American Journal of Sports Science and Medicine, 2016;4(4):109-114.

31.Takanori Noguchi, Shinichi Demura, Masashi Omoya. Accuracy of Force Exertion in Response to Demanded Forces Based on Subjective Information and Laterality. American Journal of Sports Science and Medicine, 2014;2(5):190-193.

32.Zerf Mohammed. Impact of Preventing Pregnancy Methods and Their Relationships with the Level of Growth Fitness Body Health housewife Case Women Newlyweds. American Journal of Sports Science and Medicine, 2015;3(5):90-95.

Information about the authors:

Pyatkov V.T.; http://orcid.org/0000-0001-5429-5922; info@sportscience.org.ua; Lviv State University of Physical Culture; Kostiushko str. 11, Lviv, 79000, Ukraine.

Bilinski J.; http://orcid.org/0000-0001-5429-5922; jbilinski@wsiz.rzeszow.pl; University of Information Technology and Management in Rzeszow; ul. Sucharskiego 2, Rzeszow, 35-225, Poland.

Petriv O.S.; http://orcid.org/0000-0001-5429-5922; murtagav@gmail.com; Ukrainian Defense Ministry of Sport Management; Povitroflostky Ave 6, Kyiv, 03168, Ukraine.

Magmet T.M.; http://orcid.org/0000-0001-5429-5922; post@naiau.kiev.ua; National Academy of Internal Affairs; st. Collector 4, Kyiv, 02121, Ukraine.

Cite this article as: Pyatkov VT, Bilinski J, Petriv OS, Magmet TM. Dynamic of arm's micro movements of elite athlete in Olympic exercises Rapid Fire Pistol and Air Pistol. Physical education of students, 2017;2:90-95. doi:10.15561/20755279.2017.0207

The electronic version of this article is the complete one and can be found online at: http://www.sportedu.org.ua/index.php/PES/issue/archive

This is an Open Access article distributed under the terms of the Creative Commons Attribution License, which permits unrestricted use, distribution, and reproduction in any medium, provided the original work is properly cited (http://creativecommons.org/licenses/by/4.0/deed.en).

Received: 13.02.2017

Accepted: 09.03.2017; Published: 04.04.2017 